\title{
The Green Deer: Chaya as a Potential Source of Protein for the Ancient Maya
}

\author{
Henry P. Schwarcz, Anabel Ford (D), Martin Knyf, and Anil Kumar
}

\begin{abstract}
Archaeologists have used isotope analysis $\left(\delta^{13} C, \delta^{15} N\right)$ of the collagen of human bones, as well as knowledge of available nutrients, to infer that the diet of the ancient Maya was drawn from the resources of the Maya forest landscape. The interpretations have focused on plant carbohydrates from maize and protein dominated by white-tail deer. The $\delta^{15} N$ values of bone collagen suggest that most of the protein requirements of the Maya could have been satisfied with a mixture of wild animal flesh and wild and cultivated plants including beans. Chaya, Cnidoscolus aconitifolius, domesticated before the Spanish conquest, has a high-protein content and the potential to have been a significant contributor to the ancient Maya diet. Chaya is easily propagated, is grown in home gardens by the Maya today, and is a significant part of the local traditional diet. Chaya's stable isotopic composition of carbon $\left(\delta^{13} \mathrm{C}\right)$ resembles that of other terrestrial plants, but its values for nitrogen $\left(\delta^{15} \mathrm{~N}\right)$ are significantly higher. Consumption of chaya would result in slightly higher $\delta^{15} N$ values in humans than expected from the consumption of terrestrial animals. Thus, chaya is situated well as a component of the complex, diverse, and varied diets of ancient Mesoamericans.
\end{abstract}

Keywords: Maya diet, chaya, protein, isotope ratios, deer

Los arqueólogos han utilizado análisis isotópicos $\left(\delta^{13} C, \delta^{15} N\right)$ de colágeno de huesos humanos, así como el conocimiento de los nutrientes disponibles, para inferir que la dieta de los antiguos mayas se extrajo de una gran variedad de recursos del paisaje forestal maya. Las interpretaciones se han centrado en los carbohidratos vegetales del maíz y la proteína dominada por ciervos de cola blanca. Los valores de colágeno óseo $\left(\delta^{15} N\right)$ sugieren que la mayoría de los requisitos proteicos de los mayas podrían haber sido satisfechos con una mezcla de carne animal silvestre, plantas silvestres y plantas cultivadas que incluían frijoles. La chaya, Cnidoscolus aconitifolius, domesticada antes de la conquista española, tiene un alto contenido proteico y posee el potencial de haber sido un elemento importante de la antigua dieta maya. La chaya se propaga fácilmente. Hoy en día, los mayas la cultivan en sus huertos familiares y es una parte importante de la dieta tradicional local. La composición de isotópos estables de carbono de la chaya $\left(\delta^{13} C\right)$ se asemeja a la de otras plantas terrestres, pero sus valores de nitrógeno $\left(\right.$ de $\left.\delta^{15} \mathrm{~N}\right)$ son significativamente más altos. El consumo de chaya produciría valores ligeramente superiores de $\delta^{15} N$ en humanos, a lo esperado por el consumo de animales terrestres. La chaya se sitúa bien entre los componentes de las complejas, diversas y variadas dietas de los antiguos pueblos mesoamericanos.

Palabras claves: dieta maya, chaya, proteína, relación de isótopos ratios, venado

\section{Complexity of the Maya Diet}

I $\mathrm{t}$ is well known that the diet of the ancient Maya was derived from the Maya forest within which they thrived (Figure 1). Its diversity is, in part, revealed in the plant and animal remains of the excavated middens, as well as the isotopes of the collagen in human bones of the area. This evidence of plant and animal consumption represents resources from a complex landscape ranging from uplands to wetlands and from the home infields to agricultural

Henry P. Schwarcz and Martin Knyf $\square$ School of Earth, Environment and Society, McMaster University, Hamilton, ON, Canada

Anabel Ford (ford@ucsb.edu, corresponding author) — MesoAmerican Research Center, University of California, Santa Barbara, CA, USA

Anil Kumar $\mathbf{~ I n d i a n ~ G r a s s l a n d ~ a n d ~ F o d d e r ~ R e s e a r c h ~ I n s t i t u t e , ~ J h a n s i , ~ U t t a r ~ P r a d e s h , ~ I n d i a ~}$

Latin American Antiquity 33(1), 2022, pp. 175-186

Copyright (C) The Author(s), 2021. Published by Cambridge University Press on behalf of the Society for American Archaeology. This is an Open Access article, distributed under the terms of the Creative Commons Attribution licence (https://creativecommons.org/licenses/by/4.0/), which permits unrestricted re-use, distribution, and reproduction in any medium, provided the original work is properly cited.

doi:10.1017/laq.2021.71 


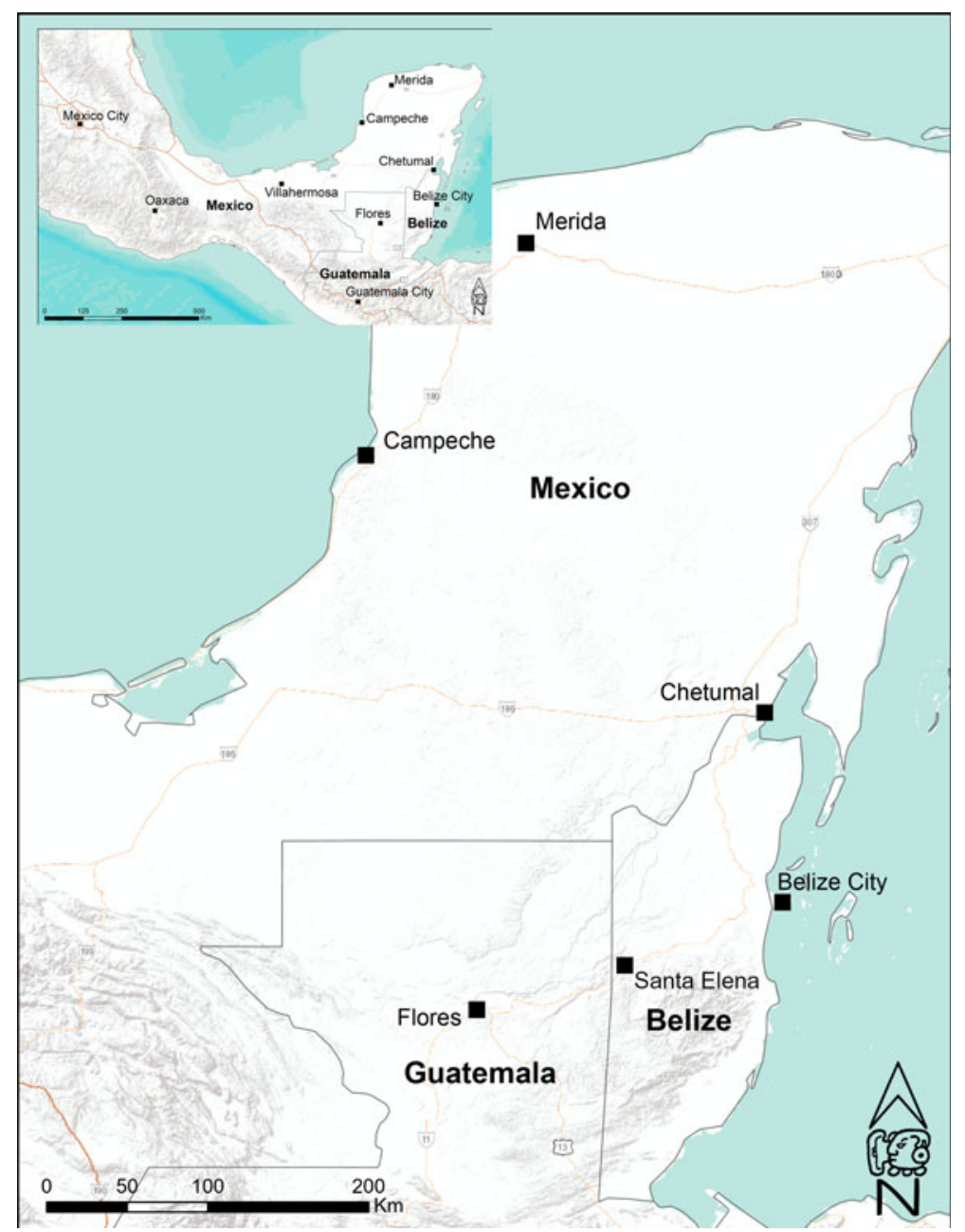

Figure 1. Map of the Maya area with place names indicated (MesoAmerican Research Center UCSB).

outfields (Ardren and Miller 2020; Emery 2007; Emery and Thornton 2008; Fedick 2020; Ford 2020; McNeil 2020; Slotten et al. 2020). The varied uses of fields and forests inferred archaeologically is consistent with the observations at the time of the sixteenth-century Spanish conquest and among traditional contemporary Maya (Colunga-Garcia Marín and ZizumboVillarreal 2004; Terán and Rasmussen 1995; Varela Scherrer and Liendo Stuardo 2021).

Food resources have distinct stable isotopic values $\left(\delta^{13} \mathrm{C}, \delta^{15} \mathrm{~N}\right)$ that are incorporated into the bones and teeth of humans and animals (Schwarcz and Schoeninger 1992) with seasonal and longterm variations averaged over about 10-20 years. Recognizing that the diet must include both carbohydrates and protein, interpretations of consumption of major food components have been based on isotopic analyses of human skeletal collagen and their relationship to the compositions of the sources of carbohydrate and protein.

Although an enormous variety of plants have been used by the Maya for carbohydrates, maize is considered among the most important and is well documented in the Mesoamerican and Maya diet, past and present. Measured isotopically for carbon, $\delta^{13} \mathrm{C}$, human bone collagen generally averages around -8 to $-10 \%$, which has been accepted as an indicator of a high degree of consumption of maize, although there is archaeological evidence of diverse plant consumption in the diet of the Maya (Farahani 
et al. 2017; Fedick 2020; McNeil 2020; Terán and Rasmussen 1994; Trabanino 2014).

Humans require approximately $50-60 \mathrm{~g}$ of protein per day (Young and Pellett 1987). Based on skeletal remains at Maya archaeological sites and using the $\delta^{15} \mathrm{~N}$ values of human collagen, many previous scholars have inferred that the principal source of protein for the Maya was the flesh of terrestrial animals, principally whitetailed deer (Odocoileus virginianus; Emery and Thornton 2008). Faunal remains of many other animals (ca. 100 species) characteristic of the full range of habitats of home gardens, fields, and forests have also been found that contributed to the protein intake (Emery and Thornton 2008; Varela Scherrer and Liendo Stuardo 2021). The isotopic composition of most of these remains would not have differed significantly from deer. Deer-browsing ecotone habitat dwellerswere a common resource at the time of the conquest, and it was noted that they appeared "tame" as part of the varied domesticated landscape of the Maya (Diaz del Castillo 1927 [1568]); Landa 1937; Pohl and Feldman 1982).

The Maya consumed, in addition, a wide variety of animals, birds, and insects. At sites near the coast, fish and other marine foods would have been available. Populations living on rivers or lakes would have had access to aquatic sources such as fish and turtles. All of these would have provided an adequate protein supply when present in sufficient amount (Emery 2007; Emery and Thornton 2008; Vanderwarker 2006).

The Maya today know and use nearly 500 native edible plants (Fedick 2020), many of which have been identified in the archaeological record (Dussol et al. 2017; Thompson et al. 2015; Trabanino and Liendo Stuardo 2016). Only a few, however, would provide significant amounts of protein. Legumes, including beans, containing $\sim 20 \%$ dry weight of protein, were cultivated across Mesoamerica and provided about three times more protein content than most other vegetables. Seeds are another important source of protein; for example, tambulo squash seeds contain $40 \mathrm{wt} \%$ protein, whereas chia seeds contain $20 \mathrm{wt} \%$.

Chaya, a plant widely cultivated by the modern Maya (Everton 2012:104, 135, 225, 427; Sterling 2014), has a notably high-protein content and thus presents a potential contributor of protein to ancient Maya diets. Evidence confirms early domestication, likely in the central Maya Lowlands, and is documented at the time of the conquest (Colunga-Garcia Marín and Zizumbo-Villarreal 2004). Today, it is a common ingredient in contemporary cooking across the Maya area (Kuti and Torres 1996; Standley 1930; Standley and Steyermark 1949; Sterling 2014:128-132). We propose that chaya was an important source of protein in the ancient Maya diet. In this article we examine its isotopic and nutritional composition and suggest how it could have been a contributor to the total protein intake of the Maya at times and places where animal-based protein supplies were limited.

\section{Isotopic Paleodiet Studies}

Interpretation of human diet is partly based on the isotopic values of human tissues and, in particular, the $\delta^{13} \mathrm{C}$ and $\delta^{15} \mathrm{~N}$ values of bone collagen. $\delta^{13} \mathrm{C}$ values tend to be about $5 \%$ o higher than that of the food consumed (whether starch, fat, or protein). About $95 \%$ of plant species use the $\mathrm{C}_{3}$ pathway to fix carbon and as a result have $\delta^{13} \mathrm{C}$ values around $-26 \%$. Maize and amaranths instead use the $\mathrm{C}_{4}$ pathway to fix carbon, resulting in higher $\delta^{13} \mathrm{C}$ values averaging around $-12 \%$. In addition, the Maya ate succulent plants such as prickly pear that use the CAM pathway to fix carbon and have $\delta^{13} \mathrm{C}$ values intermediate between $\mathrm{C}_{3}$ and $\mathrm{C}_{4}$ plants. Variation in the $\delta^{13} \mathrm{C}$ value of human collagen is largely attributable to variations in the relative amount of $\mathrm{C}_{4}$ versus $\mathrm{C}_{3}$ plant foods consumed.

In general, the $\delta^{15} \mathrm{~N}$ values of human collagen tend to be about 3\%o higher than that of the food consumed because of the trophic-level effect (Schoeninger and DeNiro 1984; Schoeninger and Moore 1992; Schwarcz 2014). Where humans have access to adequate supplies of high-protein foods, nonessential amino acids tend to be routed directly from diet to collagen synthesis (Schwarcz 2014), causing the $\delta^{13} \mathrm{C}$ value of collagen to be biased toward that of the high-protein foods. Average $\delta^{13} \mathrm{C}$ and $\delta^{15} \mathrm{~N}$ values provide clues to the long-term ( $\sim 10-20$ years) foods consumed and can be interpreted based on the flora and faunal collections from archaeological contexts. 


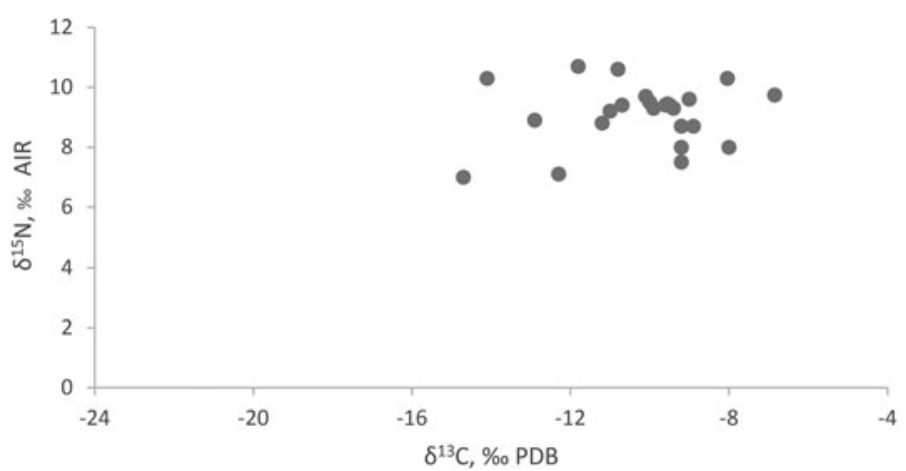

Figure 2. Average isotopic composition $\left(\delta^{13} \mathrm{C}, \delta^{15} \mathrm{~N}\right)$ of human bone collagen from Maya sites (after Scherer 2007).

Based on research reported by Scherer (2017) and the wider comparative data provided by Scherer and colleagues (2007:Figure 6), the average $\delta^{13} \mathrm{C}$ value of human collagen varies from -15 to $-7 \%$ o (Figure 2 ). These relatively high values are attributed to widespread consumption of maize (Kennett et al. 2020; Reed 1998; Scherer et al. 2007; Tykot et al. 1996; White and Schwarcz 1989; White et al. 1993), although amaranths and CAM plants also contribute to the higher $\delta^{13} \mathrm{C}$ values.

The average $\delta^{15} \mathrm{~N}$ values of human collagen at those archaeological sites discussed by Scherer and colleagues (2007:91-92, 97) vary from about 8 to $10 \%$, averaging $9.1 \pm 1.0 \%$. It is noteworthy that this average remains constant across space and from Preclassic to Postclassic times, indicating that the Maya had reliable sources of protein with an average $\delta^{15} \mathrm{~N}$ of $6 \pm 1 \%$. This measure overlaps with the $\delta^{15} \mathrm{~N}$ value of the flesh of $\mathrm{C}_{3}$-consuming animals such as the herbivorous white-tailed deer and red brocket deer (Mazama spp.), as well as the flesh of other terrestrial animals (Emery 2007).

Other possible protein sources may have included aquatic and marine fish, amphibians, shellfish, and insects. Human consumers of fish (marine or freshwater) tend to harvest fish with high trophic levels with $\delta^{15} \mathrm{~N}$ values of $10 \%$ 18\%o (Katzenberg et al. 2012; Schoeninger and DeNiro 1984; Schwarcz et al. 2014; Williams et al. 2009)—with the result that humans whose diets included marine foods could show increased $\delta^{15} \mathrm{~N}$ values. Considering the sites from which data were compiled by Scherer and colleagues (2007:91; Figure 2), we can compare $\delta^{15} \mathrm{~N}$ values for sites of varying distance from a marine coast (Figure 3). There is a very slight trend of increasing $\delta^{15} \mathrm{~N}$ with decreasing distance from the coast, suggesting only a modest influence of the consumption of marine foods.

Insects range widely in their $\delta^{15} \mathrm{~N}$ values depending on trophic level and feeding habits, from values as low as $0 \%-12 \%$ o (Albers et al. 2006; Feldhaar et al. 2010; Quinby et al. 2020), and it is difficult to estimate what would have been their net effect on human consumer $\delta^{15} \mathrm{~N}$ values. Most shellfish tend to have low $\delta^{15} \mathrm{~N}$ values because they are either herbivores or feed on suspended particulate organic matter (Schwarcz et al. 2014).

Beans were widely consumed by the Maya and are a rich source of protein. However, the average $\delta^{15} \mathrm{~N}$ value of beans is $3.9 \pm 0.8 \%$ (Warriner et al. 2013). This is substantially lower than the average value of the flesh of animals, including deer, as well as the recorded values of Maya bone collagen (Scherer at al. 2007). If beans had been a major source of protein, this would result in $\delta^{15} \mathrm{~N}$ values for human collagen significantly lower than are observed in ancient Maya populations, ranging between 6 and 12\%o, as shown in Figure 2.

\section{Chaya as a Source of Protein}

Leaves of the edible "tree spinach" chaya (Cnidoscolus aconitifolius [Mill.] I.M.Johnst.), contain about $30 \%$ protein (dry basis: Peregrine 1983; Sarmiento-Franco et al. 2003). This is high compared with other plant-based food (12-25 wt \%). Only one common Mesoamerican food plant has appreciably high-protein levels: 


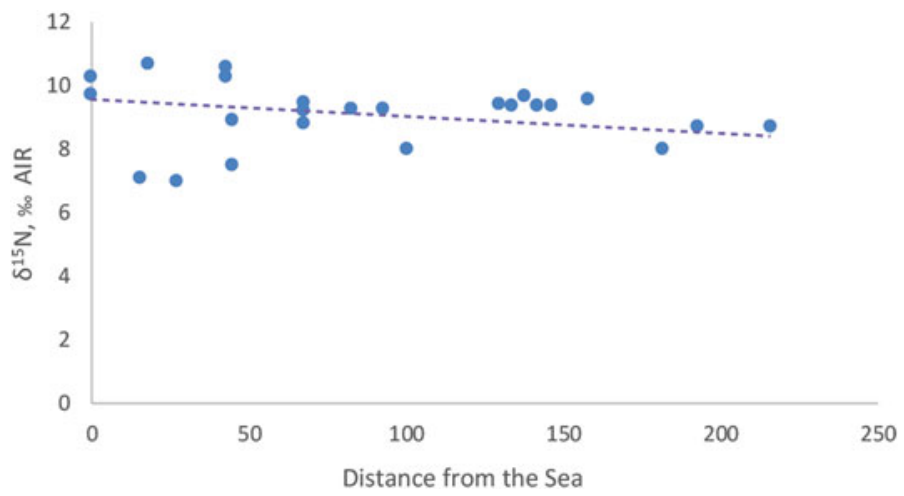

Figure 3. $\delta^{15} \mathrm{~N}$ of average human collagen from Maya sites plotted against distance of the site from the seacoast to assess the influence of marine fish as a nutrient by humans.

beans (19.5\%-24.8\%; Carbas et al. 2020). Importantly, unlike beans, the protein of chaya is complete and contains all essential amino acids in adequate dietary proportions.

Chaya is a member of the drought-resistant Euphorbiaceae family. Indigenous to the Maya Lowlands, the wild variety is characterized by seriously irritating urticating hairs on the stems and leaves that burn at the touch, a reaction that lasts for several days, which is the chief disincentive to its collection. As a result of domestication, a crop species, C. aconitifolius, was developed to express greatly reduced or nonexistent urticating hairs, making the leaves easier to harvest (Figure 4; Ross-Ibarra and Molina-Cruz 2002; see also Colunga-Garcia Marín and ZizumboVillarreal 2004; Roys 1933). Today chaya is considered a favored plant among the Maya (Ardren and Miller 2020; McNeil 2020), and there is evidence suggesting that domestication extended over millennia (Colunga-Garcia Marín and May Pat 1992; Ross-Ibarra and Molina-Cruz 2002).

Chaya has been difficult to distinguish prehistorically. However. Miksicek (1983:102-103), studying floral remains at the Pulltrouser Swamp in Belize, proposed a tentative identification of five fragments of charred Euphorbiaceae root as chaya. Chaya produces few pollen grains (RossIbarra and Molina-Cruz 2002) and is thus unlikely to appear in palynological records. Chemical digestion of chaya leaves failed to yield siliceous phytoliths, but roots have not been examined and deserve consideration and should be tested for them (Morell-Hart, personal communication 2020). Although domesticated chaya rarely produces seeds, it is easily propagated from stem cuttings (Ross-Ibarra 2003:289).

The productivity of chaya is remarkably high (Bendaña 2020). Peregrine (1983) estimated that a fully mature $C$. aconitifolius plant produces $4.9-7.4 \mathrm{~kg}$ of fresh leaves per month, with annual yields ranging from 5 to 8 tons per ha ${ }^{-1}$. Cultivation of chaya in 50-70 ha for a population of 10,000 people would yield about $400 \mathrm{~g}$ per day of leaves per person, or about $120 \mathrm{~g}_{\text {protein }} \mathrm{d}^{-1}$. Assuming an average human protein requirement of $60 \mathrm{~g}$ per day (Young and Pellett 1987), this could more than satisfy human needs. Dispersed within the traditional infield home gardens and outfield areas of Maya communities, the protein-rich chaya would form part of the polyculture milpa forest garden cycle (Ardren and Miller 2020; Bendaña 2020; Ford 2020; Ford and Clarke 2019; Ford and Nigh 2015) and would meet the protein requirements of Maya populations.

Chaya flourishes across Mesoamerica as a large shrub with many lush leaves and with multiple sturdy branches that exude a latex sap (see Landa 1937). Recognized as a native crop and identified in the conquest and colonial literature (Colunga-Garcia Marín and May Pat 1992; Colunga-Garcia Marín and Zizumbo-Villarreal 2004; Mariaca Méndez 2015; Terán and Rasmussen 1994), chaya was then, as it is today, eaten as a green vegetable by the Maya (Landa 1937). It is prepared in soups, tamales, and tortillas, as well as in a fresh green drink and as an infusion (Greenberg 2003; Kuti and Torres 1996; Standley 1930; Standley and Steyermark 1949; Sterling 2014:128-132). 


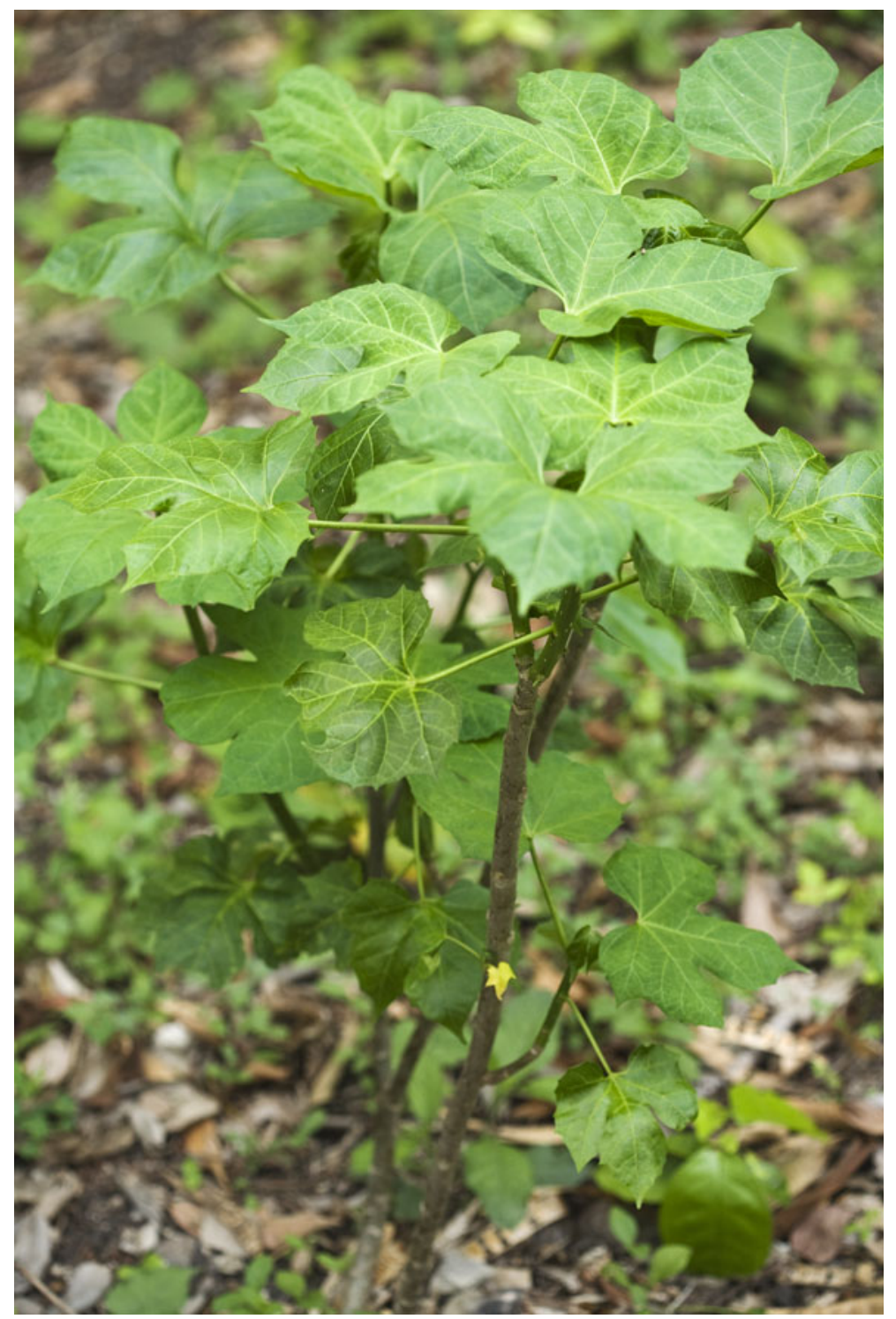

Figure 4. A young chaya shrub growing from recent cuttings (from MacduffEverton.com). (Color online)

The prevalence of chaya in the Maya region today attests to its continued importance. It is found in dooryards, hedges, and around dwellings and is commonly used as a living fence protecting garden plots in the Lowlands of Guatemala, Mexico, and Belize (Everton 2012). Its ubiquity in the Lowland Maya area and its incorporation into traditional recipes indicate its deep roots in Maya cooking (Anderson 2003; Coe 1994; De Clerck and Negreros-Castillo 2000; Everton 2012; Fedick 2020; Hamman 1998; Lundell
1938; McNeil, 2020; Steggerda 1943; Sterling 2014; Terán et al. 1998; Williams 1981). To determine whether chaya might have contributed protein to ancient Maya diet, we analyzed the $\delta^{15} \mathrm{~N}$ and $\delta^{13} \mathrm{C}$ of the leaves from modern plants.

\section{Isotopic and Chemical Analysis of Chaya Samples}

Chaya leaves were sampled from C. aconitifolius plants growing in home gardens of Santa Elena 
Town and Santa Familia Village in the Cayo District, Belize. In addition, we purchased fresh chaya leaves in a farmers market in the city of Campeche, Mexico. The leaves were air dried and stored at $25^{\circ} \mathrm{C}$ in preparation for analysis.

Samples were analyzed both raw and boiled. Three raw leaves from each of the Santa Elena plants were crushed while frozen in a Spex cryomill; the resulting powder was dried at $60^{\circ}$ C. Leaves were boiled in water for 10 minutes and dried, reserving the water. The water remaining from the boiling procedure was lyophilized. Leaves were heated five times in a microwave oven for one minute each. The leaves from Campeche and Santa Familia were sun-dried before analysis. To test for intra-leaf variation, pieces were removed from the bottom edge and middle of a leaf, as well as the stem (identified in Table 1 as leaf parts).

All stable isotope measurements were performed using a Costech elemental analyzer (Costech ECS 4010) connected to a ThermoFinnigan DeltaPlus XP. The separated $\mathrm{CO}_{2}$ and $\mathrm{N}_{2}$ were carried in a helium stream to the mass spectrometer via a Conflo III coupling. Both carbon and nitrogen were analyzed on the same samples. The results are reported as $\delta=\{($ Rsample/Rstandard $)-1\} \times 1,000$ where $\mathrm{R}$ is either ${ }^{13} \mathrm{C} /{ }^{12} \mathrm{C}$ for $\delta^{13} \mathrm{C}$, with standard $=$ VPDB, or ${ }^{15} \mathrm{~N} /{ }^{14} \mathrm{~N}$ for $\delta^{15} \mathrm{~N}$ with standard $=$ atmospheric nitrogen (AIR). The precision of both $\delta^{13} \mathrm{C}$ and $\delta^{15} \mathrm{~N}$ is $\pm 0.1 \%$. The mass spectrometric analyses also gave values for the wt $\%$ $\mathrm{C}$ and $\mathrm{N}$ in the samples through measurement of the areas under the peaks for $\mathrm{m} / \mathrm{e}=44$ and $28\left({ }^{12} \mathrm{C}^{16} \mathrm{O}_{2}\right.$ and ${ }^{28} \mathrm{~N}_{2}$, respectively). The peak intensities were calibrated by analyses of known amounts of glutamic acid. $\mathrm{N} w t \%$ values were converted to protein using the conversion factor $\mathrm{P}=6.25 \mathrm{~N}$ (Elgar et al. 2020).

The isotopic compositions of fresh, boiled, and residual solid extracted by boiling of chaya are given in Table 1. Chaya analyses for $\delta^{13} \mathrm{C}$ exhibit expected levels for a $\mathrm{C}_{3}$ plant $(\sim-27 \%)$, but surprisingly high values of $\delta^{15} \mathrm{~N}$ when compared with values for deer, beans, maize, and amaranth (Figure 5). Untreated raw chaya leaves from Santa Elena are highly enriched in ${ }^{15} \mathrm{~N}$; boiled leaves are not as enriched: $\delta^{15} \mathrm{~N}=7.7$ (Table 1). Notably, the residue extract from
Table 1. Isotopic and Protein Data Derived from Samples of Chaya and Residue from Boiling of Chaya.

\begin{tabular}{|c|c|c|c|c|c|}
\hline $\begin{array}{l}\text { Santa Elena } \\
\text { Chaya Plants }\end{array}$ & $\begin{array}{c}\delta^{13} \mathrm{C} \\
\%\end{array}$ & $\begin{array}{c}\mathrm{C} w \mathrm{t} \\
\%\end{array}$ & $\begin{array}{c}\delta^{15} \mathrm{~N}, \\
\% 0\end{array}$ & $\begin{array}{c}\mathrm{N} w \mathrm{t} \\
\%\end{array}$ & $\begin{array}{c}\text { Protein } \\
\text { wt\%* }\end{array}$ \\
\hline Raw & -26.96 & 41.4 & 10.28 & 4.95 & 30.9 \\
\hline s.d. & 0.02 & 0.2 & 0.03 & 0.06 & \\
\hline \multirow[t]{2}{*}{ Boiled } & -26.79 & 44.2 & 7.71 & 3.30 & 20.6 \\
\hline & 0.08 & 0.3 & 0.11 & 0.04 & \\
\hline \multirow[t]{2}{*}{ Boiled residue } & -26.95 & 38.3 & 10.49 & 7.27 & 45.4 \\
\hline & 0.05 & 0.3 & 0.11 & 0.07 & \\
\hline \multirow[t]{2}{*}{ Microwaved } & -26.40 & 42.3 & 8.35 & 4.32 & 27.0 \\
\hline & 0.05 & 0.0 & 0.20 & 0.09 & \\
\hline \multirow[t]{2}{*}{ Leaf 1 , parts } & -27.75 & 41.1 & 9.57 & 5.10 & 31.9 \\
\hline & 0.35 & 0.8 & 0.64 & 0.32 & \\
\hline \multirow[t]{2}{*}{ Leaf 2, parts } & -28.01 & 41.4 & 9.23 & 4.81 & 30.1 \\
\hline & 0.08 & 0.7 & 0.29 & 0.22 & \\
\hline \multirow[t]{2}{*}{ Leaf 3, parts } & -27.54 & 41.7 & 8.99 & 5.45 & 34.0 \\
\hline & 0.36 & 0.5 & 0.66 & 0.16 & \\
\hline
\end{tabular}

Other localities

\begin{tabular}{lrrrrr} 
Campeche & -27.90 & 46.44 & 11.32 & 6.52 & 40.8 \\
Chaya Plants & & & & & \\
& 0.06 & 0.35 & 0.18 & 0.01 & 0.1 \\
Santa Familia & -28.27 & 41.67 & 10.03 & 5.42 & 30.4 \\
& 0.04 & 0.04 & 0.10 & 0.03 & 3.8 \\
\hline
\end{tabular}

$*$ Protein $=\mathrm{N}$ wt $\% \times 6.25($ Elgar et al. 2020).

boiling is very rich in protein $(45 \mathrm{wt} \%$ in dried residue) and is enriched isotopically $\left(\delta^{15} \mathrm{~N}=\right.$ 10.5\%o). Samples from Santa Familia and Campeche yielded comparable isotopic results for uncooked leaves. Cooked and uncooked, the $\delta^{15} \mathrm{~N}$ values of chaya are higher than those of the meat of deer (Figure 5), the most common terrestrial source evident in middens (Emery 2007).

The protein content of dried chaya leaves $(\sim 30 \mathrm{wt} \%)$ is higher than any other plant food known for the Maya and is comparable to the protein content of some animal flesh. The fact that the $\delta^{15} \mathrm{~N}$ values exceed those of the average terrestrial sources, together with its exceptionally high-protein content, sets chaya apart from other plant foods available to the Maya, past and present. 


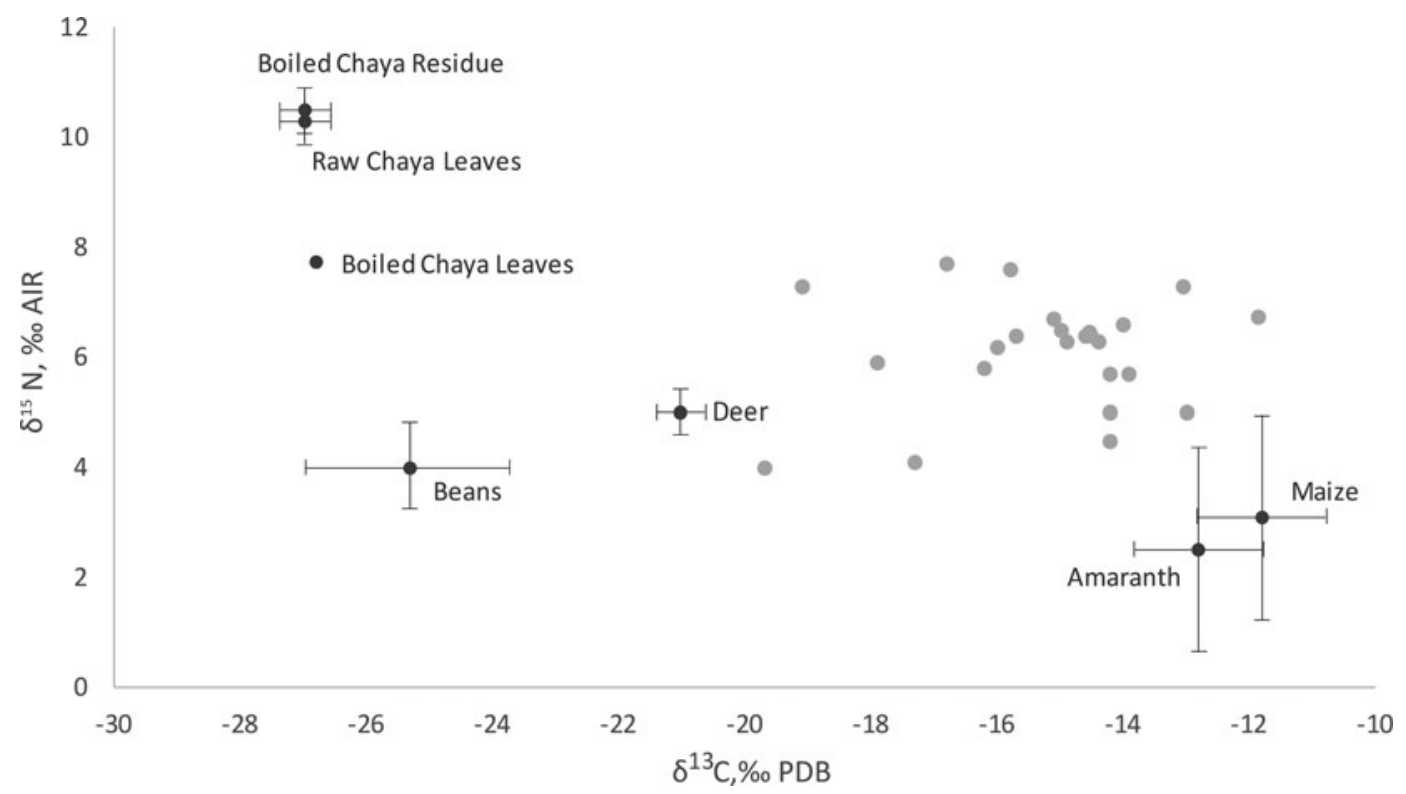

Figure 5. Isotopic compositions $\left(\delta^{13} \mathrm{C}, \delta^{15} \mathrm{~N}\right)$ of leaves of fresh chaya, boiled, and residue from boiling chaya compared with compositions of other Maya foods, and with the data in Figure 1 translated by the diet-collagen offset: $5 \%$ ofor $\delta^{13} \mathrm{C}$ and $3 \%$ for $\delta^{15} \mathrm{~N}$.

\section{The Green Deer of the Ancient Maya}

Archaeologists have viewed the main source of protein for the Maya as having been the flesh of animals (Emery 2007; Scherer 2017; Thornton et al. 2012). Given the isotopic compositions of the foods consumed by humans (Figure 2), and accounting for the isotopic offsets between collagen and diet due to trophic and biochemical effects by $5 \%$ for $\delta^{13} \mathrm{C}$ and $3 \%$ for $\delta^{15} \mathrm{~N}$ (Schwarcz 2014), the average $\delta^{15} \mathrm{~N}$ value of deer flesh $(5.2 \pm 0.6 \%)$ is close to known dietary values for $\delta^{15} \mathrm{~N}$ of humans. The human diet, however, would have been influenced by all food consumed, including low- $\delta^{15} \mathrm{~N}$ foods (Figure 5), particularly maize and beans (Warinner et al. 2013). The average $\delta^{15} \mathrm{~N}$ value of human collagen of $9 \pm 1 \%$ represents the balance of all sources contributing to the diet. These sources include animal flesh, aquatic and marine foods, low- $\delta{ }^{15} \mathrm{~N}$ plants, and additional contributions with high $\delta{ }^{15} \mathrm{~N}$ values to attain the evident averages. We propose that chaya, a plant-based food with high $\delta^{15} \mathrm{~N}$, is a potential source of nutrients, including protein, calcium, iron, and vitamin C, for the ancient Maya (Kuti and Kuti
1999; Kuti and Torres 1996). Chaya would complement terrestrial and aquatic protein sources and match their generally high $\delta^{15} \mathrm{~N}$ values.

If, as we have suggested, chaya leaves and boiled residue were sources of dietary protein, what effect would this have on the isotopic composition of bone collagen? And, can we distinguish the presence of chaya in human diet from other foods that would have been available to the ancient Maya? As we have noted, variation in the $\delta^{13} \mathrm{C}$ value of human collagen is attributable to variations in the relative amount of $\mathrm{C}_{4}$ plant foods consumed. The average of $-27 \%$ for chaya is comparable to the general values of all other food plants. Therefore, the $\delta^{13} \mathrm{C}$ values of collagen would not be able to distinguish chaya as a component of the Maya diet.

The $\delta^{15} \mathrm{~N}$ values of chaya range from 8 to $10 \%$. As we know, other plant foods known to have been consumed by the Maya, including beans and maize, have low $\delta^{15} \mathrm{~N}$ values (Warinner et al. 2013). Although both beans and chaya were certainly contributors to the protein in the Maya diet, only chaya and fish with high trophic levels could have contributed to the 
higher $\delta^{15} \mathrm{~N}$ values in some Maya humans. In fact, a simple mixture of chaya leaves and beans alone could account for the observed $\delta^{15} \mathrm{~N}$ value in the diet of the Maya (Figure 5). This suggests that chaya could have been a significant component of the Maya diet.

The nutritional properties of chaya support it as a potentially important contributor to the protein supply of ancient Maya communities, just as it is with their contemporary descendants. Beans have always been considered important in the Mesoamerican and Maya diet. Yet, based on their low $\mathrm{N}$ isotopic composition, beans could not have been a major protein source for humans. Interestingly, although the Maya had many plant foods available, a diet of beans and chaya could account for the observed range of $\delta^{15} \mathrm{~N}$ values observed in ancient Maya populations.

Although the extensive data on faunal remains show that Maya were consuming terrestrial animals and some marine and aquatic organisms, we know that the Maya had access to a variety of plant-based foods. New analytical strategies such as aDNA of food residues in the calculus of human teeth (Scott et al. 2021), as well as the expansion of investigations of the roots of chaya, may provide direct data on its use. Undoubtedly, the Maya protein diet contribution would involve a mixture of foods, possibly including meat, chaya, and other plant foods grown from home gardens and agricultural fields that provided subsistence for the population. Managing the complex Maya forest landscape, the Maya clearly devised a stable basis for access to protein and essential amino acids that came from both animals and plants. Chaya is recorded at the time of conquest, and the evidence points to its origins and domestication over thousands of years. This suggests that chaya could have been among the important food sources of the Maya. The domestication and use of this nutritious perennial vegetable would have been consistent with the extensive environmental knowledge of traditional Maya farmers. The ubiquity of chaya in the Maya area today and its obvious potential as a green protein source situate it well as a component of the complex, diverse, and multifaceted diets characteristic of ancient Mesoamericans.
Acknowledgments. The isotopic and chemical analyses of chaya were supported by a Discovery Grant No. RGPIN3669-2016 to Henry P. Schwarcz from the Natural Sciences and Engineering Research Council of Canada. Chaya was sourced from home gardens and markets in the Maya area. We also appreciate the improvements of the reviewers that made our points clearer. Insights into the importance of chaya in the local Maya diet are derived from Master Forest Gardeners of Belize, Guatemala, and Mexico. They have shared their extensive knowledge of plants.

Data Availability Statement. All primary data were generated by the authors. The primary data on chaya were gathered in the Maya area of Belize, Guatemala, and Mexico. Comparative data are available in published literature where referenced. The analytical processes were conducted at McMaster University. The samples were gathered by Anabel Ford, and analyses were conducted by Martin Knyf and Henry P. Schwarcz.

\section{References Cited}

Albers, Derk, Matthias Schaefer, and Stefan Scheu 2006 Incorporation of Plant Carbon into the Soil Animal Food Web of an Arable System. Ecology 87:235-245.

Anderson, Eugene N.

2003 Traditional Knowledge of Plant Resources. In The Lowland Maya Area: Three Millennia at the HumanWildland Interface, edited by Arturo Gómez-Pompa, Michael F. Allen, Scott L. Fedick, and Juan J. JiménezOsornio, pp. 533-550. Food Products Press, New York.

Ardren, Traci, and Stephanie Miller

2020 Household Garden Plant Agency in the Creation of Classic Maya Social Identities. Journal of Anthropological Archaeology 60:101212.

Bendaña, Guillermo

2020 La Chaya: Valor nutritivo, cultivo, utilización. Selfpublished manuscript. Electronic document, https:// www.researchgate.net/publication/338902144, accessed September 8, 2021.

Carbas Bruna, Nelson Machado, David Oppolzer, Luis Ferreira, Marcelo Queiroz, Carla Brites, Eduardo Rosa, and Ana Barros

2020 Nutrients, Antinutrients, Phenolic Composition, and Antioxidant Activity of Common Bean Cultivars and their Potential for Food Applications. Antioxidants 9(2):186. DOI:10.3390/antiox9020186.

Coe, Sophie D.

1994 America's First Cuisines. University of Texas Press, Austin.

Colunga-Garcia Marín, Patricia, and Filogonio May Pat

1992 El sistema milpero y sus recursos fitogenéticos. In La modernización de la milpa en Yucatán: Utopía o realidad, edited by Daniel Zizumbo Villarreal, Christian $\mathrm{H}$. Rasmussen, Luis Manuel Arias Reyes, and Silvia Terán Contreras, pp. 97-134. CICY-DANIDA, Mérida, Yucatán, Mexico.

Colunga-Garcia Marín, Patricia, and Daniel Zizumbo-Villarreal

2004 Domestication of Plants in Maya Lowlands. Economic Botany 58:S101-S110.

De Clerck, F. A. J., and P. Negreros-Castillo

2000 Plant Species of Traditional Mayan Homegardens of 
Mexico as Analogs for Multistrata Agroforests. Agroforestry Systems 48:303-317.

Diaz del Castillo, Bernal

1927 [1568] The True History of the Conquest of Mexico, Written in the Year 1568. Translated by Maurice Keatinge. National Travel Club, New York.

Dussol, Lydie, Elliott Michelle, Dominique Michelet, and Philippe Nondedeo,

2017 Ancient Maya Sylviculture of Breadnut (Brosimum alicastrum Sw.) and Sapodilla (Manilkara zapota (L.) P. Royen) at Naachtun (Guatemala): A Reconstruction Based on Charcoal Analysis. Quaternary International 457:29-42.

Elgar, David F., Jeremy P. Hill, Stephen E. Holroyd, and Gaile S. Peddie

2020 Comparison of Analytical Methods for Measuring Protein Content of Whey Protein Products and Investigation of Influences on Nitrogen Conversion Factors. International Journal of Dairy Technology 73:790-794.

Emery, Kitty F.

2007 Assessing the Impact of Ancient Maya Animal Use. Journal for Nature Conservation 15:184-195.

Emery, Kitty F., and Erin Kennedy Thornton

2008 Zooarchaeological Habitat Analysis of Ancient Maya Landscape Changes. Journal of Ethnobiology 28:154-178.

Everton, Macduff

2012 The Modern Maya: Incidents of Travel and Friendship in Yucatán. University of Texas Press, Austin.

Farahani, A., Katherine L. Chiou, Anna Harkey, Christine A. Hastorf, David L. Lentz, and Payson Sheets

2017 Identifying "Plantscapes" at the Classic Maya Village of Joya de Cerén, El Salvador. Antiquity 91:980 997.

Fedick, Scott L.

2020 Maya Cornucopia: Indigenous Food Plants of the Maya Lowlands. In The Real Business of Ancient Maya Economies, edited by David A. Freidel, Marilyn A. Masson, and Arthur A. Demarest, pp. 224-237. University Press of Florida, Gainesville.

Feldhaar, Heike, Gerhard Gebauer, and Nico Blüthgen

2010 Stable Isotopes: Past and Future in Exposing Secrets of Ant Nutrition (Hymenoptera: Formicidae). Myrmecological News 13:3-13.

Ford, Anabel

2020 The Maya Forest: A Domesticated Landscape. In The Maya World, edited by Scott R. Hutson and Traci Ardren, pp. 519-539. Routledge, London.

Ford, Anabel, and Keith C. Clarke

2019 Linking the Past and Present of the Ancient Maya: Lowland Use, Population Distribution, and Density in the Late Classic. In Handbook of Historical Ecology and Applied Archaeology, edited by Christian Isendahl and Daryl Stump, pp. 156-183. Oxford University Press, Oxford.

Ford, Anabel, and Ronald Nigh

2015 The Maya Forest Garden: Eight Millennia of Sustainable Cultivation in the Tropical Woodlands. Left Coast Press, Santa Rosa, California.

Greenberg, Laurie S. Z.

2003 Women in the Garden and Kitchen: The Role of Cuisine in the Conservation of Traditional House Lot Crops among Yucatec Mayan Immigrants. In Women and Plants: Gender Relations in Biodiversity Management and Conservation, edited by Patricia L. Howard, pp. 51-65. Zed Books, London.
Hamman, Cherry

1998 Mayan Cooking: Recipes from the Sun Kingdom of Mexico. Hippocrene Books, New York.

Katzenberg, M. Anne, Hugh G. McKenzie, Robert J. Losey, Olga I. Goriunova, and Andrzej Weber

2012 Prehistoric Dietary Adaptations among HunterFisher-Gatherers from the Little Sea of Lake Baikal, Siberia, Russian Federation. Journal of Archaeological Science 39:2612-2636.

Kennett, Douglas J., Kieth M. Prufer, Brendan J. Culleton, Richard J. George, Mark Robinson, Willa R. Trask, Gina M. Buckley, et al.

2020 Early Isotopic Evidence for Maize as a Staple Grain in the Americas. Science Advances 6:aba3245. DOI:10. 1126/sciadv.aba3245.

Kuti, Joseph O., and H. O. Kuti

1999 Proximate Composition and Mineral Content of Two Edible Species of Cnidoscolus (Tree Spinach) Plant Foods for Human Nutrition. Plant Foods for Human Nutrition 53:275-283.

Kuti, Joseph O., and Eliseo S. Torres

1996 Potential Nutritional and Health Benefits of Tree Spinach. In Progress in New Crops, edited by Jules Janick, pp. 516-520. ASHS Press, Arlington, Virginia.

Landa, Diego de

1937 Yucatan: Before and after the Conquest. Translated by William Gates. Global Grey, London. https://www. globalgreyebooks.com/yucatan-before-and-after-theconquest-ebook.html, accessed September 8, 2021.

Lundell, Cyrus Longworth

1938 Plants Probably Utilized by the Old Empire Maya of Petén and Adjacent Lowlands. Papers of the Michigan Academy of Science, Arts and Letters 24 (Part I):37-56.

Mariaca Méndez, Ramón

2015 La Milpa maya Yucateca en el siglo XVI: Evidencias etnohistóricas y conjeturas. Etnobiología 13:1-25.

McNeil, Cameron L.

2020 Favored Plants of the Maya. In The Maya World, edited by Scott R. Hutson and Traci Ardren, pp. 183-202. Routledge, London.

Miksicek, Charles H.

1983 Macrofloral Remains of the Pulltrouser Area: Settlements and Fields. In Pulltrouser Swamp: Ancient Maya Habitat, Agriculture, and Settlement in Northern Belize, edited by Billie L. Turner and Peter D. Harrison, pp. 94 104. University of Texas Press, Austin.

Peregrine, W. T. H.

1983 Chaya (Cnidoscolus aconitifolius) - A Potential New Vegetable Crop for Brunei. Tropical Pest Management 29:39-41.

Pohl, Mary, and Larry H. Feldman

1982 The Traditional Role of Women and Animals in Lowland Maya Economy. In Maya Subsistence: Studies in Memory of Dennis E. Puleston, edited by Kent V. Flannery, pp. 295-311. Academic Press, New York.

Quinby, Brandon M., J. Curtis Creighton, and Elizabeth A. Flahert

2020 Stable Isotope Ecology in Insects: A Review. Ecological Entomology 45:1231-1246.

Reed, David M

1998 Ancient Maya Diet at Copán, Honduras. PhD dissertation, Department of Anthropology, Pennsylvania State University, University Park.

Ross-Ibarra, Jeffrey

2003 Origen y domesticación de la chaya (Cnidoscolus 
aconitifolius Mill I. M. Johnst): La espinaca Maya. Mexican Studies/Estudios Mexicanos 19:287-302.

Ross-Ibarra, Jeffrey, and Alvaro Molina-Cruz

2002 The Ethnobotany of Chaya (Cnidoscolus aconitifolius ssp. aconitifolius Breckon): A Nutritious Maya Vegetable. Economic Botany 56:350-365.

Roys, Ralph

1933 The Book of Chilam Balam of Chumayel. Publication No. 438. Carnegie Institution, Washington, DC.

Sarmiento-Franco, Luis, Carlos A. Sandoval-Castro, Jim M. McNab, Rosario Quijano-Cervera, and Raul R. Reyes-Ramirez

2003 Effect of Age of Regrowth on Chemical Composition of Chaya (Cnidoscolus aconitifolius) Leaves. Journal of the Science of Food and Agriculture 83:609-612.

Scherer, Andrew K.

2017 Bioarchaeology and the Skeletons of the PreColumbian Maya. Journal of Archaeological Research 25:133-184.

Scherer, Andrew K., Lori E. Wright, and Cassady J. Yoder

2007 Bioarchaeological Evidence for Social and Temporal Differences in Diet at Piedras Negras, Guatemala. Latin American Antiquity 18:85-104.

Schoeninger Margaret, and Michael DeNiro

1984 Nitrogen and Carbon Isotopic Composition of Bone Collagen from Marine and Terrestrial Animals. Geochimica et Cosmochimica Acta 48:625-639

Schoeninger, Margaret J., and Katherine Moore

1992 Bone Stable Isotope Studies in Archaeology. Journal of World Prehistory 6:247-296.

Schwarcz, Henry P.

2014 Human Physiology in Relation to Isotopic Studies of Ancient and Modern Humans. In Treatise on Geochemistry, Vol. 14, edited by Heinrich D. Holland and Karl K. Turekian, pp. 357-369. Elsevier, Amsterdam.

Schwarcz, Henry P., Brian S. Chisholm, and Meghan Burchell

2014 Isotopic Studies of the Diet of the People of the Coast of British Columbia. American Journal of Physical Anthropology 155:460-468.

Schwarcz, Henry P., and Margaret J. Schoeninger

1992 Stable Isotope Analyses in Human Nutritional Ecology. Yearbook of Physical Anthropology 34:283321.

Scott, A., Robert C. Power, Victoria Altmann-Wendling, Michel Artzy, Mario A. S. Martin, Stefanie Eisenmann, Richard Hagan, et al.

2021 Exotic Foods Reveal Contact between South Asia and the Near East during the Second Millennium BCE. PNAS 118(2):e20149561173. DOI:10.1073/ pnas.2014956117.

Slotten, Venicia, David Lentz, and Payson Sheets

2020 Landscape Management and Polyculture in the Ancient Gardens and Fields at Joya de Cerén, El Salvador. Journal of Anthropological Archaeology 59:101-191.

Standley, Paul Carpenter

1930 Flora of Yucatan. Field Museum of Natural History 3:328-329.

Standley, Paul Carpenter, and Julian A. Steyermark

1949 Flora of Guatemala. Fieldiana: Botany 24:59-60.

Steggerda, Morris

1943 Some Ethnological Data Concerning One Hundred Yucatan Plants. Bureau of American Ethnology Bulletin 136(29):189-226.
Sterling, David

2014 Yucatan: Recipes from a Culinary Expedition. University of Texas Press, Austin.

Terán, Silvia, and Christian H. Rasmussen

1994 La milpa de los Mayas: La agricultura de los Mayas prehispánicas y actuales en el noreste de Yucatán. Gobierno del Estado de Yucatán, Mérida, México.

1995 Genetic Diversity and Agricultural Strategy in 16th Century and Present-Day Yucatecan Milpa Agriculture. Biodiversity and Conservation 4:363-381.

Terán, Silvia, Christian H. Rasmussen, and Olivio May Cauich 1998 Las plantas de la milpa entre los mayas: etnobotánica de las plantas cultivadas por campesinos mayas en las milpas del noreste de Yucatán, México. Yucatán: identidad y cultural maya. Universidad Autónoma de Yucatán, Centro de Investigaciones Regionales "Dr. Hideyo Noguchi”, Yucatán, México. https://www.mayas.uady.mx/ exposiciones/exp_04.html.

Thompson, Kim P., Angela Hood, Dana Cavallaro, and David L. Lentz

2015 Connecting Contemporary Ecology and Ethnobotany to Ancient Plant Use Practices of the Maya at Tikal. In Tikal: Paleoecology of an Ancient Maya City, edited by David L. Lentz, Nicholas P. Dunning, and Vernon L. Scarborough, pp. 124-151. Cambridge University Press, New York.

Thornton, Erin Kennedy, Kitty F. Emery, Camilla Speller, David Steadman, Ray Matheny, and Dongya Yang

2012 Earliest Mexican Turkeys (Meleagris gallopavo) in the Maya Region: Implications for Pre-Hispanic Animal Trade and the Timing of Turkey Domestication. PLoS ONE 7(8):e42630.

Trabanino, Felipe

2014 El uso de las plantas y el manejo de la Selva por los antiguos mayas de chinikiha: interacciones sociedad y medio ambiente a traves de la paleoetnobotanica y de la antracologia. PhD dissertation, Instituto de Investigaciones Antropológicas, Universdad Nacional Autónoma de México, Mexico City.

Trabanino, Felipe, and Rodrigo Liendo Stuardo

2016 Arqueología de las plantas en Chinikihá. Paper presented at the First Conference of the Intercontinental Society for American Anthropology, Panama.

Tykot, Robert, Nikolaas van der Merwe, and Norman Hammond

1996 Stable Isotope Analysis of Bone Collagen, Bone Apatite and Tooth Enamel in the Reconstruction of Human Diet: A Case Study from Cuello, Belize. In Archaeological Chemistry: Organic, Inorganic, and Biochemical Analysis, edited by Mary Virginia Orna, pp. 355-365. American Chemical Society, Washington, DC.

Vanderwarker, Amber M.

2006 Farming, Hunting, and Fishing in the Olmec World. University of Texas Press, Austin.

Varela Scherrer, Carlos Miguel, and Rodrigo Liendo Stuardo 2021 Aprovechamiento del paisaje y manejo de la fauna en Palenque, Chiapas. Ancient Mesoamerica, in press. DOI: $10.1017 /$ S095653612100002X.

Warinner Christina, Nelly R. Garcia, and Noreen Tuross

2013 Maize, Beans and the Floral Isotopic Diversity of Highland Oaxaca, Mexico. Journal of Archaeological Science 40:868-873.

White, Christine D., Paul F. Healy, and Henry P. Schwarcz

1993 Intensive Agriculture, Social Status, and Maya Diet at Pacbitun, Belize. Journal of Anthropological Research 49:347-375. 
White, Christine D., and Henry P. Schwarcz

1989 Ancient Maya Diet as Inferred from Isotopic and Elemental Analysis of Human Bone. Journal of Archaeological Science 16:451-474.

Williams, Jocelyn S., Christine D. White, and Fred J. Longstaffe 2009 Maya Marine Subsistence: Isotopic Evidence from Marco Gonzalez and San Pedro, Belize. Latin American Antiquity 20:37-56.

Williams, Louis O.

1981 The Useful Plants of Central America. Ceiba 24(14):1-381.
Young, V. R., and P. L. Pellett

1987 Protein Intake and Requirements with Respect to Diet and Health. American Journal of Clinical Nutrition 45:1323-1343.

Submitted October 30, 2020; Revised January 26, 2021; Accepted July 28, 2021 